Available online on 15.09.2020 at http://jddtonline.info
Open Access to Pharmaceutical and Medical Research
(c) 2011-18, publisher and licensee JDDT, This is an Open Access article which permits
unrestricted non-commercial use, provided the original work is properly cited

Open $\odot$ Access

Research Article

\title{
Systemic Lupus Erythematosus in Algerian Men: Clinical-Biological and Evolutionary Analysis of 19 Algerian Men
}

\section{Belmokhtar Naima Rania*1; Zemri Khalida1, Kanoun Khedoudja1; Harir Noria1; Bachaoui B.M. 2; Hebri Sid Tadj $^{3}$}

1 Molecular Microbiology, Proteomics and Health Laboratory, Faculty of Natural and Life Sciences, Djillali Liabès University of Sidi Bel Abbés, Algeria. Address: Rectorat Ex ITMA, Sidi Bel Abbes, 22000 BP.89 sidi Bel Abbes, Algeria

2 Department of Internal Medicine-Diabetes, Etablissement Hospitalier Universitaire d'ORAN 1 November 1954, Algeria. Address: BP N 4166 Ibn Rochd. Oran 31000, Algeria

3 Department Internal Medicine, University Hospital Centre CHU Dr HASSANI Abdelkader. Sidi Bel Abbes, Algeria. Address: Rue Belahcen Mourad, Sidi Bel Abbes 22000, Algeria

\begin{abstract}
Objectives: the aim of our study was to precise the epidemiological, clinicobiological, immunological, and evolutionary profile of systemic lupus erythematosus in Algerian men.

Methods: A retrospective multicenter study was carried out on 19 Algerian male lupus patients, diagnosed according to the ACR and SLICC criteria and followed between 2006 and 2019 on a total of 203 cases of systemic lupus erythematosus in western Algeria.

Results: 203 SLE patients were included, 19 men (9.4\%) and 184 women (90.6\%) with F/ M sex ratio of 9.68 / 1 . The mean age at diagnosis was $33 \pm 9.49$ years. The most frequent clinical manifestations were joint involvement (84.2\%), cutaneous (68.4\%) and hematolo gical disorder (63.2\%). 15.8\% had lupus nephropathies with the predominance of class IV; Raynaud's syndrome and neuropsychiatric involvement were found in $26.3 \%$. Comparison of these results with those of 184 lupus women showed a significant frequency of mucosal ulcer ( $\mathrm{p}=0.000011$ ) and neuropsychiatric damage in men $(\mathrm{p}=0.011)$, while alopecia in women $(\mathrm{p}=0.021)$. As well, hypocomplementemia ( $\mathrm{p}=0.0004)$, anti $-\mathrm{Sm}$ antibodies $(p=0.053)$ and anti Ribosome $(p=0.028)$ were more frequent in men; while anti-SSA $(p=0.003)$ and anti-SSB ( $=0.011)$ antibodies were more frequent in women. Survival of lupus men was equal to $100 \%$ throughout the studied period.
\end{abstract}

Conclusion: Male lupus is rare. The Algerian man suffers from SLE in a less severe form compared to other data in the literature, which is manifested by a lower frequency of organ damage and mortality.

Keywords: Male lupus, epidemiology, clinical polymorphism, evolutionary profile, western Algeria.

Article Info: Received 09 July 2020; Review Completed 13 August 2020; Accepted 18 August 2020; Available online 15 September 2020

Cite this article as:

Belmokhtar NR, Zemri K, Kanoun K, Harir N, Bachaoui BM; Hebri ST, Systemic Lupus Erythematosus in Algerian Men: Clinical-Biological and Evolutionary Analysis of 19 Algerian Men, Journal of Drug Delivery and Therapeutics. 2020; 10(5):18-23 http://dx.doi.org/10.22270/jddt.v10i5.4334

*Address for Correspondence:

Belmokhtar Naima Rania, Molecular Microbiology, Proteomics and Health Laboratory, Faculty of Natural and Life Sciences, Djillali Liabès University of Sidi Bel Abbés, Algeria

\section{INTRODUCTION:}

Systemic lupus erythematosus (SLE) is an organ-specific autoimmune disease of unknown and possibly heterogeneous etiology ${ }^{1}$. It is associated with high clinical polymorphism and characterized by multifactorial dysfunction of the immune system with the production of a wide variety of autoantibodies directed primarily against nuclear antigens 2, 3. The disease preferentially affects women of childbearing age but more rarely males ${ }^{4}$. The clinical, biological and progressive features of lupus in men vary from one study to another.
In order to contribute to the precision of the epidemiological, clinical, biological, immunological and evolutionary profile of SLE in the Algerian population, we carried out a first multicentric study on Algerian male patients with SLE.

\section{MATERIAL AND METHOD:}

This is a retrospective multicenter study of 19 male lupus patients, diagnosed and followed between January 2006 to December 2019 in the University Hospital of ORAN (EHUO) and the ABDELKADER HASSANI University Hospital of Sidi Bel Abbes (CHU-SBA) West of Algeria. All patients are Algerians, adults, and met the lupus criteria of the ACR 1997 
and SLICC of 2012 05. Patients under the age of 16 were excluded because they were followed by a different medical team (pediatrics). One hundred and eighty-four (184) female lupus diagnosed during the same period, in the same hospitals above-mentioned, were used as a control population to compare the clinic-biological and immunological manifestations and evolution between the two sexes.

The standardized data collection included demographic, clinical, laboratory data, 2002 SLICC criteria and 1997 ACR criteria 06, therapeutic interventions and iatrogenic complications. Information on deaths during hospitalization was collected from hospital records and death registers. Noted that all recorded deaths were female, ethnicity could not be determined since Algerians are generally descended from either Berbers or Arabs, which are the two predominant ethnicities in Algeria. For associated autoimmune diseases, the definition criteria were specific to each disease: American-European criteria for GougerotSjögren syndrome ${ }^{07}$, Sydney international criteria for SAPL 08, joint ACR / EULAR criteria for Rheumatoid Arthritis 09.

Our patients were divided into two groups according to sex (Male and Female), whose studied parameters and qualitative variables were expressed in numbers and percentages, the quantitative variables on average with their standard deviations and / or 95\% confidence interval calculated according to the normal distribution. In the case of non-normal distribution, the quantitative variables were described with the median. The $\mathrm{Chi}^{2}$ test of Person with Fisher correction was used for the comparison of the numbers. Significance was retained for values of $p \leq 0.05$.

\section{RESULTS:}

Nineteen male lupus, or $9.4 \%$, all white, meeting the criteria of the ACR, were collected during a period of 13 years out of a total of 203 systemic lupus with a percentage equal to $90.6 \%$ of female lupus, which gave a female / male sex ratio of $9.68 / 1$. The mean age at diagnosis was 33 years \pm 9.49 (range: 18 and 51 years), identical to that of the female group 29.11 years \pm 13.84 . The mean duration of patient follow-up was 12.3 years. A family history of autoimmune disease in the first degree was found in 17 patients $(89.5 \%)$, it was familial lupus in 03 cases (15.8\%), diabetes in 03 cases $(15.8 \%)$, Arterial hypertension (hypertension ) in 04 cases (21.1\%), diabetes + HTA in 03 cases $(15.8 \%)$, and 04 patients (21.1\%) had familial TCDS from other AI diseases (Rheumatoid Arthritis, Thyroid, Psoriasis, Vitiligo).

A triggering factor was noted in 08 patients (42.10\%) (viral infection of the CMV and EBV type in 02 cases, sun exposure in 04 cases and 02 cases by psychological stress due to the death of one of the relatives). No case of induced lupus has been observed.

The frequency of clinicobiological and immunological manifestations were shown in Tables 1 and 2 . Joint involvement represented the most dominated clinical manifestation (84.2\%) comprising polyarthralgia in 10 cases and non-erosive arthritis in 06 cases, followed by cutaneous manifestations with a percentage equal to $68.3 \%$ (photosensitivity, malar rash, oral ulcerations in 10 cases, i.e. $52.6 \%)$, Raynaud syndrome (26.3\%), neuropsychiatric involvement noted in $26.3 \%$, pulmonary involvement $(15.8 \%)$, pericarditis found in only one case $(5.3 \%)$. Gastrointestinal manifestations were rare, only one patient has gastrointestinal bleeding.
Class IV lupus nephropathy found in 02 cases and only one case with end-stage renal failure requiring the use of hemodialysis.

Haematological involvement was very common with a percentage equal to $63.2 \%$ of cases. The anemia observed in $47.4 \%$ of cases was autoimmune hemolytic (AHAI) in $15.3 \%$ of cases. Six patients developed Leukopenia (31.6\%), five patients had Lymphopenia (26.3\%), Thrombocytopenia in 07 cases $(36.8 \%)$ and neutropenia in only one case.

Regarding serological tests, all patients presented positive ANA $(100 \%)$. The speckled appearance (57.8\%) and the homogeneous appearance $(31.5 \%)$ were the most common appearances. The mixed homogeneous + speckled appearance was rare $(10.5 \%)$. Anti-native DNA antibodies were present in $68.4 \%$ of patients, anti-Sm in $47.4 \%$, antiRNP in $31.6 \%$. Anti-SSA antibodies found in $26.3 \%$ of patients, anti-Ribosome in 02 cases $(10.5 \%)$. The antinucleosome, anti-centromere and anti Scl-70 antibodies were each noted in a single case (5.3\%). No case of antiphospholipid syndrome has been observed. Hypocomplementemia was observed in nine cases (47.4\%).

The inflammatory syndrome was very remarkable in our patients, the sedimentation rate (SV) was accelerated in $89.4 \%$ of patients, with an average of the SV (1st hour) equal to $56.84 \pm 37.35 \mathrm{~mm} / \mathrm{h}$ and SV (2nd hour) equal at $86.22 \pm$ $38.33 \mathrm{~mm} / \mathrm{h}$. C reactive protein (CRP) was positive in $73.6 \%$ of cases with a mean equal to $18.10 \pm 24.61$.

The comparison of male and female lupus (Tables 1 and 2) showed a significant increase in the frequency of oral and nasal ulcerations $(p=0.000011)$ in men, neuropsychiatric damage $(\mathrm{p}=0.011)$ in men and non-scaring alopecia $(\mathrm{p}=$ 0.021 ) in women.

Other manifestations were seen more frequently in men, but the difference was not significant. These were general signs such as: fever $(21.1 \%$ vs $9.2 \%)$, asthenia $(57.9 \%$ vs $39.1 \%)$, weight loss (15.8\% vs $19 \%$ ) and anorexia (5.3\% vs $9.8 \%$ ). Joint involvement represented the highest percentage in both sexes ( $84.2 \%$ vs. $75 \%$ ) followed by skin involvement (68.4\% vs. $71.7 \%$ ) with photosensitivity (52.6\% vs. $39.7 \%)$, malar rash (52.6\% vs $54.9 \%)$, hematologic involvement (63.2\% vs $72.8 \%)$, lupus nephropathy (15.8\% vs $26.6 \%)$, pulmonary involvement $(15.8 \%$ vs $35.3 \%)$. Pericarditis, ocular involvement and gastrointestinal involvement were each noted in a single case $5.3 \%$ vs $6.5 \%, 2.7 \%, 2.2 \%$ respectively in females.

In our series, autoimmune hemolytic anemia (AIHA) was more frequent in men compared to female (15.8\% vs. $8.7 \%)$. As well, leukopenia $(31.6 \%$ vs. $20.7 \%)$ and thrombocytopenia $(36.8 \%$ vs. $21.7 \%)$. In contrast lymphopenia was less common in men (26.3\% vs. $32.6 \%)$.

Regarding the serological profile, the comparison of the positivity of the anti-native DNA antibodies in 19 male patients was high compared to female patients $(n=102)$ $(68.4 \%$ vs $55.4 \%)$. The prevalence of anti-Sm ( $p=0.053)$, anti-Ribosome ( $\mathrm{p}=0.028)$ antibodies was significantly increased in men patients, while anti-SSA $(p=0.003)$, antiSSB $(p=0.011)$ and anti-Histone $(p=0.051)$ were significantly increased in females patients.

The treatment included hydroxychloroquine in 18 cases (94.7\%), corticosteroid therapy in 13 cases $(68.4 \%)$ at a rate of $1 \mathrm{mg} / \mathrm{kg} / \mathrm{d}$ for an average duration of 18 months with recourse to boluses of Solumédrol $(1 \mathrm{~g} / \mathrm{j} \times 3 \mathrm{j})$ in 6 cases, associated with cyclophosphamide in 08 cases $(42.1 \%)$. Nonsteroidal anti-inflammatory drugs (NSAIDs) received in 02 
cases and only one case received biotherapy based on Rituximab and IV immunoglobulins.

The course was marked by relapses in 10 cases (52.6\%) of which 02 cases had corticosteroid-induced diabetes, 03 patients osteoporosis and 1 case progressed to end-stage renal disease. Complete remission was observed in 02 patients with a follow-up of 12, 24, 126 months. Regarding deaths during hospitalization, no case has been recorded. The survival at 1 and 5 years was respectively 100\% and $80 \%$.

In the female group $(\mathrm{n}=184)$, the overall mortality was $4.89 \%(\mathrm{n}=9$ ) during hospitalization. It was linked to cardiovascular involvement in 03 cases, end stage renal disease ( 04 cases) and two cases by ischemic stroke.

Table 1: Comparison of clinical manifestations in 203 men and women with SLE:

\begin{tabular}{|l|c|c|c|}
\hline & Male & Female & $P$ value \\
\hline Mean age & $(\mathrm{n}=19) \%$ & 0.044 \\
General signs : & $33 \pm 9.49$ & $29.11 \pm 11.36$ & NS \\
$\quad$ Fever & $(04) 21.1$ & $(17) 9.2$ & NS \\
Asthenia & $(11) 57.9$ & $(72) 39.1$ & NS \\
Weight loss & $(03) 15.8$ & $(35) 19$ & NS \\
$\quad$ Anorexia & $(01) 5.3$ & $(18) 9.8$ & NS \\
\hline Articular manifestation & $(01) 5.3$ & $(18) 9.8$ & NS \\
\hline Dermatological disorders & $(16) 84.2$ & $(138) 75$ & NS \\
\hline Malar rash & $(13) 68.4$ & $(132) 71.7$ & NS \\
\hline Photosensitivity & $(10) 52.6$ & $(101) 54.9$ & 0.000011 \\
\hline Mucosal ulcer & $(10) 52.6$ & $(73) 39.7$ & 0.021 \\
\hline Alopecia & $(10) 52.6$ & $(24) 13$ & NS \\
\hline Haematological disorder & 0 & $(41) 22.3$ & NS \\
\hline Raynaud's syndrome & $(12) 63.2$ & $(134) 72.8$ & NS \\
\hline Renal involvement & $(05) 26.3$ & $(47) 25.5$ & NS \\
\hline Pericarditis & $(03) 15.8$ & $(49) 26.6$ & NS \\
\hline Lung damage & $(01) 5.3$ & $(12) 6.5$ & 0.011 \\
\hline Neuropsychiatric & $(03) 15.8$ & $(65) 35.3$ & $(12) 6.5$ \\
\hline
\end{tabular}

NS: non significatif

Table 2: Comparison of biological and serological abnormalities in 203 lupus males and females.

\begin{tabular}{|l|c|c|c|}
\hline & $\begin{array}{c}\text { Male } \\
(\mathrm{n}=19) \%\end{array}$ & $\begin{array}{c}\text { Female } \\
(\mathrm{n}=184) \%\end{array}$ & $P$ value \\
\hline Antinuclear antibody & $(19) 100$ & $(146 / 155) 79.3$ & NS \\
\hline Anti-dsDNA & $(13) 68.4$ & $(102 / 155) 55.4$ & NS \\
\hline Anti-Sm & $(09) 47.4$ & $(48 / 155) 26.1$ & NS \\
\hline Anti-RNP & $(06) 31.6$ & $(32 / 155) 17.4$ & 0.003 \\
\hline Anti-SSA & $(05) 26.3$ & $(62 / 155) 33.7$ & 0.011 \\
\hline Anti-SSB & 0 & $(32 / 155) 17.4$ & 0.051 \\
\hline Anti Histone & 0 & $(4 / 155) 2.2$ & 0.028 \\
\hline Anti Ribosome & 0 & $(25 / 155) 13.6$ & NS \\
\hline APL & $(02) 10.5$ & $(38) 20.7$ & NS \\
\hline Leucopenia & $(05) 26.3$ & $(60) 32.6$ & NS \\
\hline Lymphopenia & $(07) 36.8$ & $(40) 21.7$ & 0.0004 \\
\hline Thrombopenia & $(03) 15.8$ & $(16) 8.7$ & 022 \\
\hline AIHA & $(09) 47.4$ & & \\
\hline $\begin{array}{l}\text { Hypocomplementemia } \\
\text { (C3 et C4) }\end{array}$ & & $(59 / 78) 32.1$ & \\
\hline
\end{tabular}

Anti-dsDNA: anti-double-stranded -DNA; AIHA : autoimmune hemolytic anemia ; APL : anti-phospholipid ; NS : non significatif 
Table 3: Frequency of the main clinical and biological manifestations in our series and in the literature.

\begin{tabular}{|c|c|c|c|c|c|c|c|c|c|c|c|c|c|c|}
\hline \multirow{5}{*}{$\begin{array}{c}\text { ACR } 1982 \\
\text { Criteria } \\
\\
\begin{array}{c}\text { Number of } \\
\text { patients }\end{array}\end{array}$} & \multicolumn{2}{|c|}{ Our study } & \multicolumn{2}{|c|}{ Tunisia } & \multirow{4}{*}{\multicolumn{2}{|c|}{$\begin{array}{c}\text { Europe } \\
\text { (Cervera) } \\
{[12]} \\
\text { M\% F\% }\end{array}$}} & \multirow{4}{*}{\multicolumn{2}{|c|}{$\begin{array}{c}\text { North } \\
\text { America } \\
\text { (Kaufman) } \\
{[11]} \\
\text { M\% F\% }\end{array}$}} & \multirow{3}{*}{\multicolumn{2}{|c|}{$\begin{array}{c}\text { Latin America } \\
\text { (Costallat) } \\
{[29]}\end{array}$}} & \multicolumn{4}{|c|}{ Asia } \\
\hline & \multirow{3}{*}{ M\% } & \multirow{3}{*}{$\mathrm{F} \%$} & \multirow{3}{*}{\multicolumn{2}{|c|}{$\mathrm{M} \% \quad \mathrm{~F} \%$}} & & & & & & & \multicolumn{2}{|c|}{ (Koh) [30] } & \multicolumn{2}{|c|}{ (Pande) [31] } \\
\hline & & & & & & & & & & & \multirow[t]{2}{*}{$\mathrm{M} \%$} & \multirow[t]{2}{*}{$\mathrm{F} \%$} & \multirow{2}{*}{ M\% } & \multirow[t]{2}{*}{$\mathrm{F} \%$} \\
\hline & & & & & & & & & $\mathrm{M} \%$ & $\mathrm{~F} \%$ & & & & \\
\hline & 19 & 184 & 24 & 271 & 92 & 908 & 52 & NA & 18 & 254 & 61 & 86 & 39 & 243 \\
\hline $\begin{array}{l}\text { Mean age } \\
\text { attainmant }\end{array}$ & 33 & 29.11 & 31.75 & 30.58 & NA & NA & 34 & NA & 21.36 & 26.53 & 28.2 & NA & 26 & NA \\
\hline \multicolumn{15}{|c|}{ ACR 1982 Criteria } \\
\hline Malar rash \% & 52.6 & 54.9 & 71 & 61 & 49 & 59 & 40 & 27 & 33 & 50 & 56 & 69 & 66.7 & 71.6 \\
\hline $\begin{array}{c}\text { Photosensitivity } \\
\%\end{array}$ & 52.6 & 39.7 & 41 & 46 & 43 & 45 & 33 & 29 & 33 & 44 & 29.5 & 18.6 & 56.4 & 65.4 \\
\hline Mucosal ulcer \% & 52.6 & 13 & 12.5 & 16 & 19 & 24 & 21 & 19.4 & 11 & 11 & 18 & 16 & 66.4 & 74.1 \\
\hline Alopecia\% & 0 & 22.3 & 12.5 & $34^{*}$ & NA & NA & 3 & NA & 44 & 62 & NA & NA & 71.8 & 84.4 \\
\hline $\begin{array}{c}\text { Raynaud's } \\
\text { syndrome \% }\end{array}$ & 26.3 & 25.5 & 25 & 22.5 & 30 & 34 & 33 & NA & 33 & 46 & NA & NA & 30.8 & 37.9 \\
\hline $\begin{array}{c}\text { Articular } \\
\text { manifestation \% }\end{array}$ & 84.2 & 75 & 95 & 90 & 74 & $85^{*}$ & 94 & 71 & 83 & 90 & NA & NA & 77.8 & NA \\
\hline $\begin{array}{c}\text { Renal } \\
\text { involvement \% }\end{array}$ & 15.8 & 26.6 & 66 & 55 & 48 & 39 & 65 & $21 *$ & $77^{*}$ & 39 & 72.1 & 74.4 & 61.5 & 68.3 \\
\hline Pericarditis \% & 5.3 & 9.2 & 37.5 & 26.6 & NA & NA & 33 & NA & 33 & 24 & 8.2 & 8.1 & 10.3 & 21.8 \\
\hline $\begin{array}{c}\text { Neuropsychiatric } \\
\% \\
\end{array}$ & 26.3 & 10.9 & 12.5 & 14 & $26^{*}$ & $27^{*}$ & 42 & $25.8^{*}$ & 05 & 10 & 24 & 39.5 & 28.2 & $37.4^{*}$ \\
\hline Leucopenia \% & 31.6 & 20.7 & 46 & 44.6 & NA & NA & 44 & 12.9 & 11 & 20 & 36 & $59^{*}$ & 15.4 & 17.3 \\
\hline Thrombopenia \% & 36.8 & 21.7 & 12.5 & 16.5 & 26 & 22 & 40 & 21 & $27^{*}$ & 10 & NA & NA & 7.7 & 16 \\
\hline AIHA $\%$ & 15.8 & 8.7 & 12.5 & 6 & 12 & 08 & 13 & 14 & NA & NA & 09 & 15 & 7.7 & 9.9 \\
\hline $\begin{array}{l}\text { Antinuclear } \\
\text { antibody \% }\end{array}$ & 100 & 79.3 & 100 & 91.7 & 97 & 96 & 98 & NA & 100 & 93 & 92 & 86 & NA & NA \\
\hline Anti-dsDNA \% & 68.4 & 55.4 & 82 & 73.3 & 86 & 77 & 70 & 61.3 & 33 & 35 & 36 & 49 & 30.8 & 27.2 \\
\hline Anti-Sm \% & 47.4 & 26.1 & 44 & 59 & 13 & 10 & 23 & 2.9 & $50^{*}$ & 18 & 09 & 27 & NA & NA \\
\hline Anti-RNP \% & 31.6 & 17.4 & NA & NA & 09 & 14 & 21 & NA & 50 & 77 & NA & NA & NA & NA \\
\hline Anti-SSA \% & 26.3 & 33.7 & 50 & 53 & 15 & 27 & 18 & 20 & 66 & 63 & 20.9 & $67.4^{*}$ & NA & NA \\
\hline Anti-SSB \% & 0 & 17.4 & 25 & 35 & 13 & 20 & 05 & 22.2 & 0 & 14 & 0 & $16.3^{*}$ & NA & NA \\
\hline $\begin{array}{l}\text { Complementary } \\
\text { Consumption \% }\end{array}$ & 47.4 & 32.1 & 82 & 75 & NA & NA & NA & NA & NA & NA & NA & NA & 43.6 & 61.3 \\
\hline
\end{tabular}

*: P significance level; $M$ : male ; $F$; femele ; NA : Data not available

Table 4: Comparison of survival rate during SLE in humans.

\begin{tabular}{|l|c|c|c|c|c|c|}
\hline Author (reference) & case numbers & \multirow{2}{*}{$\begin{array}{c}\text { Number of } \\
\text { deaths }\end{array}$} & \multicolumn{4}{|c|}{ Survival (\%) to } \\
\cline { 4 - 7 } & & 15 & 98 & 5 years & 10 years & 15 years \\
\hline Kaufman [11] & 52 & 04 & - & - & - & 51 \\
Koh [30] & 61 & 02 & - & - & - & - \\
Pande [31] & 39 & - & - & 77 & 75 & 59 \\
Wallace [32] & 63 & - & 84 & 76 & 75 & - \\
Chang [33] & 72 & - & 100 & 93 & - & - \\
Othmani [14] & 24 & 0 & 100 & 100 & & - \\
Our study & 19 & & & & & \\
\end{tabular}





\section{DISCUSSION:}

Our study is the first investigation of SLE in Algeria, it confirms the clinical and biological polymorphism of the disease in Algerian men and its similarity with other series in different regions of the world.

Lupus disease predominantly affects young women and rarely affects males. The female / male sex ratio was 9/1; $5 / 9 ; 10 ; 11 ; 11.5$ and 9.6 in our series $10,11,12,13,14$.

SLE can be found at any age, the age of onset of the disease in men is identical to that of women in our series and several international studies 14,15,16,17,18,19. An average younger age is found in Saudi Arabia 24.4 years 20, Lebanon 25 years 21, 25.8 years in Egypt 22, and significantly higher in American 11 and Japanese ${ }^{23}$ series.

The female predominance of the disease and the modulation of clinical and biological manifestations support the hypothesis of hormonal factor involvement in the etiopathogenesis of Lupus 19, 24. In favor of the deleterious role of estrogens, the worsening of the disease and relapses are triggered by pregnancy, the peri- and post-partum, as well as by the estrogen-progestogen pill 25,26 .

There is a correlation between male lupus and hyperestrogenism and hypoandrogenism 27 . Another study demonstrated 28 a decrease in the level of testosterone and free testosterone, while androstenedione and dehydroepiandrostenedione sulfate are significantly reduced, and a weak response of free testosterone to chorionic gonadotropic hormone indicating a decreased testicular function.

Lupus disease is characterized by a large clinical polymorphism, variably affecting many organs. The main clinical manifestation at the time of diagnosis and the followup varies from one study to another (Table 3). The clinical disorders studied in general are dermatological, articular, renal, hematological, cardiovascular, pleuropulmonary, and neuropsychiatric disorders with some variations depending on the studied countries. In the comparative series, certain manifestations are significantly more frequent in males. These are joint damage with a percentage greater than $70 \%$ $14,11,12,29,30,31$; our series], the characteristic malar rash of SLE; and photosensitivity occurring after sun exposure are frequently high in our study (52.6\%), and in Tunisia 14 , Europe 12 , India 31 . In the other studies the malar rash is always high but the photosensitivity is low (between 29 and $33 \%$ ) $11,29,30$. Oral ulcers are too high in our series (52.6\%) and in India (66.7\%). Unlike other studies, this sign is rarer (between 11 and 21\%) in Tunisia, Europe, North America, Latin America and Singapore 14, 12, 11, 29, 30.

Alopecia is significantly more common in females regardless of studied country (our series, 14, 11, 29, 31). However, a significant increase in this percentage was noticed among men in Latin America and India (44\% / 71.8\%). Raynaud's syndrome whatever the sex is similar between our series and that of Tunisia 14 and a little higher in Europe, North and Latin America, and in India 12,11,29,31. Pericarditis is the only cardiac involvement noted in our patients with a percentage equal to $5.3 \%$ in men and $9.2 \%$ in women, which was close to the percentage observed in Singapore 30 and lower than that noted in Tunisia ${ }^{14}$, North and Latin America ${ }^{11,29}$, and India 31.

Lupus nephropathy is varied in the literature depending on sex, age, nutrition mode... It is low, equal to $15.8 \%$ in our series and significantly greater in other populations (between 48 and 77\%) 14, 12, 11, 29, 30, 31. Concerning neuropsychiatric impairment is more frequent in Algerian men compared to female sex, it is equal to $26.3 \%$ of cases, similar to those in Europe ${ }^{12}$, close to the percentage noted in Singapore ${ }^{30}$, and greater than that of Tunisia 14 . North America recorded the highest percentage, estimated at $42 \%$ of cases ${ }^{11}$

The haematological manifestations observed in our series are comparable to the literature. It was noted in $63.2 \%$ of cases. The hemolytic anemia characteristic of SLE was noted in $15.3 \%$ of cases, close to those of Tunisia 14 , Europe 12 and North America 11, and higher than those of Singapore and India 30,31 . The leukopenia observed in $31.6 \%$ of our patients, is higher than those in India and Latin America 31,29 and lower than those in Tunisia and North America 14, 11. Thrombocytopenia noted in $36.8 \%$ of cases is higher than the percentages noted in Tunisia, North and Latin America and India $14,11,29,31$.

On the serological level, the assay of anti-nuclear antibodies (ANA) is mandatory, they were positive in all cases of our series (100\%), also in Tunisia and Latin America 14, 29, but between 79 and $98 \%$ in the other studies 11, 12, 30, 31 . The positivity of native anti-DNA antibodies noted in $68.4 \%$ of cases is lower than that observed in Tunisia, Europe and North America 14,12,11. But significantly higher than in the Indian, Singaporean, and Latin American population 31, 30, 29 . Another serological marker of anti-Sm antibody was found positive in $47.4 \%$ of cases in our population. This result is similar to that noted in Tunisia ${ }^{14}$, but higher than that noted in the European, Singaporean, and North American populations $12,30,11$.

From an evolutionary standpoint, we have noted drug complications related to the treatments administered by our patients. Two cases treated with corticosteroids (Prednisone) developed corticosteroid-induced diabetes, three cases of osteoporosis and only 1 case progressed to end-stage renal disease.

The overall survival of male lupus is reported in Table 4. In our series during the selected study period (2006-2019), survival is equal to $100 \%$, identical to that in Tunisia 14 in the first year. In addition, in the female sex, the overall mortality was $4.89 \%(n=09)$. Survival at $1 / 5$ and 10 years was $100 / 94 / 76 \%$ respectively.

The statistical comparison of our series with studies in the literature is provided for information only. Indeed, the clinical signs are not examined under the same conditions in all the studies, the prevalence of clinical and biological manifestations varies according to the time of diagnosis, the clinical services from which the patients come are heterogeneous, and even the immunological tests are not made under the same conditions and techniques.

\section{CONCLUSION:}

Algerian men with SLE have a less severe form compared to other studies in the literature, which is manifested by a lower frequency of organic attacks. Further prospective studies are needed with larger numbers to better understand this disease in humans and to assess the effectiveness of treatments.

\section{ACKNOWLEDGEMENTS:}

We would like to thank the patients for their participation and the staff at the Internal Medicine of the University Hospital of ORAN (EHUO) and the University Hospital of Sidibel-Abbes (CHU-SBA) for their invaluable support, guidance, and educational insight. 


\section{Conflict of interest declaration:}

The authors have declared that there are no potential conflicts of interest with respect to the research, authorship and/or publication of this article.

\section{REFERENCES:}

1. Iliopoulos AG, Tsokos GC. Immunopathogenesis and spectrum of infections in systemic lupus erythematosus. Semin Arthritis Rheum, 1996; 25:318-36.

2. Cecatto SB. Audition sensorioneural de perte dans le Lupus érythémateux disséminé: rapport de trois cas. Bras de l'Apocalypse. Otorrinolaringol. São Paulo, 2004; 70(3).

3. Tan EM. Antinuclear antibodies: diagnostic markers for autoimmune diseases and probes for cell biology. Adv Immunol 1989; 44:93-151

4. Ward MM, Studenski S. Systemic lupus erythematosus in men: A multivariate analysis of gender differences in clinical manifestations. J Rheumatol 1990; 17:220-4..

5. Petri M, Orbai A-M, Alarcón GS, Gordon C, Merrill JT, Fortin PR, et al. Derivation and validation of the Systemic Lupus International Collaborating Clinics classification criteria for systemic lupus erythematosus. Arthritis Rheum 2012; 64:2677-86.

6. Hochberg MC. Updating the American College of Rheumatology revised criteria for the classification of systemic lupus erythematosus. Arthritis Rheum 1997; 40:1725.

7. Vitali C, Bombardieri S, Jonsson R, Moutsopoulos HM, Alexander EL, Carsons SE, et al. Classification criteria for Sjögren's syndrome: a revised version of the European criteria proposed by the American-European Consensus Group. Ann Rheum Dis 2002; 61:554-8.

8. Miyakis S, Lockshin MD, Atsumi T, Branch DW, Brey RL, Cervera $\mathrm{R}$, et al. International consensus statement on an update of the classification criteria for definite antiphospholipid syndrome (APS). J Thromb Haemost 2006; 4:295-306.

9. Aletaha D, Neogi T, Silman AJ, Funovits J, Felson DT, Bingham CO, et al. 2010 Rheumatoid arthritis classification criteria: an American College of Rheumatology/European League Against Rheumatism collaborative initiative. Arthritis Rheum 2010; 62:2569-81.

10. Arnaud L, Fagot JP, Païta M, et al.I ncidence and prevalence of systemic lupus erythematosus: a 2010 nation-wide populationbased study using French National Administrative databases.Arthritis Rheum; 2013; 65(Suppl. 10):1067

11. Kaufman LD, Gomez Reino V, Heinicke MH, Gorevic PD. Male lupus : Retrospective analysis of the clinical and laboratory features of 52 patients, with a review of the litterature. Seminars in Arthritis Rheum 1989; 18:189-97

12. Cervera R, Khamashta MA, Font J, Sebastiani GD, Gic A, Lavilla P, et al. Systemic lupus erythematosus : Clinical and immunologic patterns of disease expression in a cohort of 1000 patients. Medicine 1993; 72:113-24.

13. Tateno S, Hiki Y, Hamaguchi K, Tsuchida H, Shigumatsu H, Robayashi Y. Study of lupus nephritis in males. Q J Med 1991; 81:296-1039.

14. Othmani S, Louzir B. Lupus systémique chez 24 hommes tunisiens: analyse clinicobiologique et évolutive. La Revue de Médecine Interne. déc 2002; 23(12):983-90

15. Louzir B, Othmani S, Ben Abdelhafidh N, Groupe d'etude du Lupus Erythemateux Systemique en Tunisie Le lupus erythemateux systemique en Tunisie. Etude multi- centrique nationale. A propos de 295 observations. Rev Med Interne 2003; 24:768-74

\section{Funding:}

The authors received no financial support for the research, authorship and/or publication of this article.

16. Bouras M, Hali F, Khadir $K$, Benchikhi H, Lupus érythémateux systémique : mortalité et facteurs de mauvais pronostic dans une série marocaine de 129 cas. Annales de Dermatologie et de Vénéréologie, 2014; 141:141-143

17. Al-Jarallah K, Al-Awadi A, Siddiqui H, Al-Salim J, Shehab D, Umamaheswaran I, et al. Systemic lupus erythematosus in Kowait- hospital based study. Lupus 1998; 7:434-8.

18. Chahade WH, Sato EL, Moura JE, Costallat LTL, Andrate LEC. Systemic lupus erythematosus in Sao Paulo/Brazil: a clinical and laboratory overview. Lupus 1995; 4:100-3.

19. Haddouk S, Ben Ayed M, Baklouti S, Hachicha J, Bahloul Z, Masmoudi H, Autoanticorps dans le lupus_erythemateux systemique: profil et correlations cliniques. Pathol Biol 2005; 53:311-7 (in French).

20. Al-Balla SR. Systemic lupus erythematosus in Saudi patients. Clin Rheumatol 1995; 14:342 \pm 346

21. Uthman I, Nasr F, Kassak K, Masri AB. Systemic lupus erythemato- sus in Lebanon. Lupus 1999; 8:713-5.

22. El Hadidi KT1, Medhat BM1, Abdel Baki NM1, Abdel Kafy H2, Abdelrahaman W1, Yousri AY1, Attia DH1, et al. Characteristics of systemic lupus erythematosus in a sample of the Egyptian population: a retrospective cohort of 1109 patients from a single center. Sage journal Lupus. 2018 May; 27(6):1030-1038

23. Michel M, Meyer O, Francès $C$, Tournier-Lasserre E, Piette JC. Bases immunologiques du lupus systémique chez l'homme. Rev Med Interne 1998; 19:726-30.

24. Vilarinho ST, Lavras-Costallat LT. Evaluation of the hypothalamic- Pituitary-Gonadal axis in males with systemic lupus erythematosus. J Rheumatol 1998; 25:1097-103

25. Talal N, Pillarisetty R, Papoian R. Experimental lupus : A disorder of immunologic regulation. Adv Nephrol 1976; 6:37-45.

26. Stojan G, Baer AN. Flares of systemic lupus erythematosus during pregnancy and the puerperium: prevention, diagnosis and management. Expert Review of Clinical Immunology. juill 2012; $8(5): 439-53$.

27. Inman RD, Jovanovic L, Mardenson JA, Longcope C. Systemic lupus erythematosus in men. Arch Intern Med 1982; 142:18135.

28. Vilarinho ST, Lavras Costallat LT. Evaluation of the hypothalamic- Pituitary-Gonadal axis in males with systemic lupus erythematosus. J Rheumatol 1998; 25:1097-103.

29. Costallat LTL, Coimbra AMV. Systemic lupus erythematosus in 18 Brazilan males : Clinical and laboratory analysis. Clin Rheumatol 1993; 12:522-5.

30. Koh WH, Fong KY, Boey ML, Feug PH. Systemic Lupus erythematosus in 61 oriental males. A study of clinical and laboratory manifestations. Br J Rheumatol 1994; 33:339-42.

31. Pandé I, Malaviya AN, Sekharan NG, Kailash S, Upal SS, Kumar A SLE in Indian men: Analysis of the clinical and laboratory features with a review of the literature. Lupus 1994; 3:181-6.

32. Wallace DJ, Podell T, Weiner J. Systemic lupus erythematosus survival pattern. Experience with 609 patients. JAMA 1981; 245:934.

33. Chang DM, Chang CC, Kuo SY, Chu SJ, Chang ML. The clinical featrures and prognosis of male lupus in Taiwan. Lupus 1998; 7:462-8. 